\title{
Latin American Journal of Aquatic Mammals

\begin{tabular}{|c|c|}
\hline \multicolumn{2}{|c|}{ Article Info } \\
\hline Manuscript type & Editorial \\
\hline \multicolumn{2}{|l|}{ Article history } \\
\hline Received & 12 October 2015 \\
\hline Received in revised form & 12 December 2015 \\
\hline Accepted & 13 December 2015 \\
\hline Available online & 26 December 2015 \\
\hline \multicolumn{2}{|c|}{$\begin{array}{l}\text { Citation: Marmontel, M., Trujillo, F., Lima, D., Van Damme, } \\
\text { P.A. and Groenendijk, J. (2015) Introduction to the Special } \\
\text { Issue on giant river otter Pteronura brasiliensis. Latin American } \\
\text { Journal of Aquatic Mammals 10(2): 70-74. } \\
\text { http://dx.doi.org/10.5597/lajam00199 }\end{array}$} \\
\hline
\end{tabular}

\section{Introduction}

The giant river otter (Pteronura brasiliensis) is a semiaquatic member of the family Mustelidae, subfamily Lutrinae, that may attain $1.8-2.0 \mathrm{~m}$ length, making it the largest among the 13 species of otters (hence the common name) and one of the largest South American carnivores. It preys mainly on fish (Duplaix, 1980; Rosas et al., 1999), but its diet may also include invertebrates and other small vertebrates (Laidler, 1984; Carter and Rosas, 1997; Ribas et al., 2012; Silva et al., 2014).

Unlike most other otter species (Bekoff et al., 1984; Kruuk, 2006), giant otters are gregarious, forming groups of up to 10 , rarely up to 20 individuals, led by a reproductive alpha couple. During most of the time these groups are cohesive, traveling, grooming, hunting, feeding and sleeping together. Group life allows giant otter to monopolize good fishing territories, share territory patrolling, confound prey and therefore catch them more easily (Mason and Macdonald, 2008), deter or defend from predators such as caimans and jaguars, share the care of cubs and possibly facilitate learning (Gittleman, 1989). Giant otters are most active during the day, especially at dawn and dusk (Leuchtenberger et al. 2014), and extremely conspicuous. They are territorial, cleaning an area and marking a territory by deposition and mixing of spraints. Territory sizes may vary (Duplaix; 1980; Laidler and Laidler, 1983; Ribas Pereira, 2004; Utreras et al., 2005; Groenendijk et al., 2015b) and dens are not always occupied (Laidler and Laidler, 1983; Marmontel pers. obs.; Leuchtenberger et al., 2013a) or some of them may be used simultaneously in the same day or week ${ }^{1}$. Giant otters are usually sympatric to Neotropical otters (Lontra longicaudis)

\section{Introduction to the Special Issue on giant river otter Pteronura brasiliensis}

\section{Miriam Marmontel $^{\dagger, *}$, Fernando Trujillo $^{\ddagger}$, Danielle Lima ${ }^{\dagger}, \varsigma$, Paul André Van Damme' and Jessica Groenendijk ${ }^{*}$}

${ }^{\dagger}$ Instituto de Desenvolvimento Sustentável Mamirauá. Estrada do Bexiga 2584, Bairro Fonte Boa, 69553-225 Tefé AM, Brazil

‡Fundación Omacha, Calle 84-21-64, Bogotá, Colombia

${ }^{\S}$ Instituto de Pesquisas Científicas e Tecnológicas do Amapá. Rodovia Juscelino Kubitschek km 10, Bairro Fazendinha, 68903-419 Macapá, AP, Brazil

'FAUNAGUA, Arocagua Norte, Sacaba-Cochabamba, Bolivia

\#San Diego Zoo Global - Institute for Conservation Research, Cusco, Peru

*Corresponding author, email: marmontel@mamiraua.org.br throughout their area of occurrence, since there are favorable conditions for the two species co-inhabiting the same area (Groenendijk et al., 2005; Silva et al., 2014).

Due to their social nature, vocal communication is also very important in giant otters. Besides being quite noisy, when they are in groups they are inquisitive, raising and lowering the neck out and into the water, to identify those who enter the territory; in this behavior they may also approach boats, which tends to frighten people. When they are alone or in few numbers, they may remain quiet and alert avoiding human disturbance ${ }^{1}$. A fortuitous attack on a careless visitor by a giant otter group with cubs in captivity in a Brazilian zoo in 1977 imprinted the image in everyone's minds (at least in Brazil) of a ferocious and aggressive species. However, there are no published reports of predatory attacks to humans in natural conditions. Territorial attacks are usually directed to conspecifics (Conover, 2002).

\section{Historical perspective}

Giant otters have been culled by fear, revenge, profit, fashion, medicinal interest or simply for being there. As other furred animals, they suffered decades of persecution for the pelt trade, even though they have the shortest fur among otters, and very little underfur (Yoxon and Yoxon, 2014). Despite the prohibition on killing, smuggling episodes have been documented in the late 1970s, in the 1990s and even in the 2000s (Laidler and Laidler, 1983; Allen, 2010)2. The present extent of poaching and illegal trade is unknown, but likely small throughout the distribution range. 
Different from the Eurasian otter Lutra lutra (Allen, 2010), giant otters have never been hunted for sport. However, parts of their bodies have been used for alleged medicinal properties (Marmontel and Lima, pers. obs) and sporadically for consumption of their meat (Gomez, 2004; Lasmar et al., 2013). Although hunting is nowadays prohibited in every country of the current distribution, local inhabitants may steal cubs from dens to raise them as pets (Lima and Marmontel, 2011).

The ever-present allegation that giant otters steal or frighten fish from fishermen's nets is a continental-wide problem (Gomez and Jorgenson, 1999; Rosas-Ribeiro et al., 2011; Lima et al., 2014)3. Giant otters may be viewed as vermin in fishing areas, and have been blamed for the disappearance of some particular fish species in parts of Brazilian, Peruvian, Ecuadorian and Colombian Amazon, as well as in the Brazilian Cerrado ${ }^{1}$ especially in relation to the Arowana fish (Osteoglossum bicirrhosum) (Recharte et al., 2008). In addition to vulnerable to current conflicts with fishermen, giant otters also suffer the effects of habitat destruction and fragmentation, building of dams, poorlyplanned tourism activities and environmental pollution, especially by oil exploitation and mining (Gutleb et al., 1997; Groenendijk et al,. 2015a).

Giant otters were originally present throughout most of northern South America, but decades of hunting greatly reduced their distribution. Of the 12 countries of known historical occurrence, the species is considered extinct in Uruguay (but see Buschiazzo et al., this issue), likely extinct in Argentina, critically endangered in Ecuador and Paraguay, threatened in Bolivia, Colombia, Peru and Venezuela, and vulnerable in Brazil. The Guianas (Guyana, French Guiana and Suriname) were considered strongholds for the species in the 1990s (Foster-Turley et al., 1990). In these countries, the species is protected by legislation; however surveillance is lacking (Groenendijk et al., 2015a). Numbers for this species as a whole are thought to range between 1000 and 5000 animals in the wild (Allen, 2010). Protected continent-wide, some populations are showing signs of slow recovery after the pelt trade era. Over the last few years, the reappearance of populations in Peru, Brazil (Amazonia, Cerrado and Pantanal), Colombia, Ecuador and Bolivia has been documented or observed (Recharte and Bodmer, 2009; Zambrana et al., 2012; Lima et al., 2013; Marmontel, pers. obs; Trujillo et al., this issue $)^{1,4}$.

\section{Research and Conservation}

A seminal work on giant otters was published by Nicole Duplaix in 1980, and during approximately two decades it

\footnotetext{
${ }^{3}$ Zucco, C.A. and Tomas, W. (2004) Diagnóstico do conflito entre os pescadores profissionais artesanais e as populaçôes de jacarés (Caiman yacare) e ariranhas (Pteronura brasiliensis) no Pantanal. In IV Simpósio sobre Recursos Naturais e Sócio-econômicos do Pantanal. Corumbá, MS 23-26 Novembro 2004: 7 pp.

${ }^{4}$ Victor Utreras, pers. comm., 16 Deciembre 2015
}

was the most important reference focusing on the species, summarizing several topics about ecology and habitat requirements, based on field trips in Suriname. In 1992 Jorge Schweizer published a popular book on giant otters reporting his observations and interpretations of behavior from a ranch in the Brazilian Pantanal. Intensive fieldwork continued that resulted in doctoral dissertations by Laidler (1984), Schenck (1999), Staib (2002, translated into a book in 2005) and Davenport (2008) in Guyana and Peru. Up until that point, however, most efforts with Pteronura were highly localized.

In June and November 2003 two workshops supported by Frankfurt Zoological Society in Peru and conducted by Jessica Groenendijk gathered 14 giant otter researchers and resulted in the publication of guidelines for standardization of survey methods (Groenendijk et al., 2005). This stimulated the initiation or continuation of several projects with giant otter in South America. Research groups were created and strengthened; today there are consolidated groups working for several years in Brazil, Bolivia and Peru. The researchers also started meeting more frequently at events such as the International Otter Colloquium and other venues to discuss subjects relevant to otter species in South America, especially Pteronura, such as its status and distribution. In recent years we have seen great advances in conceptual topics and the use of innovative techniques that have improved our knowledge on giant otter ecology. The use of new technology has aided in breaking paradigms and unveiling aspects of biology that could not be accessed in the past.

In 2007 Carter and Rosas published a work based on scientific research and on a wide compilation about the biology, ecology, biogeography and conservation of giant otter, that became one of the most complete references on the species. In the same year the first scientific capture of giant otters was performed in Cantão State Park, state of Tocantins (Brazilian Cerrado) and then replicated in other areas of Amazonia and in the Brazilian Pantanal. With the intra-peritoneal implant of a VHF transmitter and its monitoring by radio-tracking, it was possible to monitor individuals and their movement patterns not only during the dry season but also during the flood period (Silveira et al., 2011; Leuchtenberger et al., 2013a; 2015). Monitoring of giant otters in the wild has benefitted from the use of camera traps (Utreras and Pinos, 2003), helping to document behavior and pack membership as well as to understand movement patterns, including nocturnal activities (Pickles et al., 2011b, Leuchtenberger et al., 2013b).

Molecular population studies using microsatellites in the Brazilian Pantanal demonstrated that not all animals in one group are related, which contradicts the current understanding of an exclusively parent-brood model (Ribas et al., 2015) and corroborates Groenendijk et al.'s (2014) findings in Peru. The use of genetic markers also helped to define the existence of evolutionarily distinct units (Garcia et al., 2007; Pickles et al., 2011a; 2012). A new and unique evolutionarily significant unit was recently described for the 
Colombian Orinoco (Caballero et al., 2015) and the levels of genetic differentiation and diversity found in this region were an important contribution to reintroduction and captive breeding programs currently underway in Colombia. Longterm studies carried out in Manu National Park (Peru) have allowed the first analysis of demographic parameters of a giant otter population (Groenendijk et al., 2014; 2015b).

In an attempt to focus on the conservation of the giant otter, the government of Brazil developed a National Action Plan ${ }^{5}$ exclusively for the species (which until 2001 was included in the Aquatic Mammals Action Plan) with the collaboration of several researchers. The group established objectives, goals and actions to minimize the conflicts between otters and humans, promote research to better understand their biology, ecology and conservation status, identify gaps in knowledge, as well as to recover populations and suggest public education and policy. A national action plan for giant otters has also been published in Ecuador (Utreras et al., 2013) and a Colombian national action plan is currently being prepared.

\section{A Pteronura meeting in Santa Cruz, Bolivia}

During the IX Congress of Wildlife Management, in May 2010, in the city of Santa Cruz de la Sierra, Bolivia, Paul Van Damme called a meeting with attending giant otter researchers, to discuss the progress of research and conservation of Pteronura brasiliensis. The meeting took place in the International Convention Center of Santa Cruz (FEXPOCRUZ) with the participation of 13 researchers from Bolivia, Brazil, Colombia and French Guiana. During the meeting it became clear that new research was being conducted with giant otters in different countries but that few of the results were being published in the scientific literature. Fernando Trujillo proposed then the idea of producing a special issue of the Latin American Journal of Aquatic Mammals on Pteronura, which would put out a request for contributions from the region. He explained that this journal was particularly focused on aquatic mammals and that in addition to regular issues it also produced special issues focused on particular species such as franciscana (Pontoporia blainvillei) and Guiana and tucuxi dolphins (genus Sotalia). The participants of the meeting welcomed the idea and a group of Guest Editors was proposed to consolidate this initiative. In this process, the Yaqu Pacha Foundation offered the financial support for the special issue; this issue is the result of that process.

\section{Contents of the Special Issue}

This special issue on Pteronura brings you one review, five articles and six notes. In their review, Duplaix et al. provide an update on the new information generated on the ecology

${ }^{5}$ ICMBio (2014) Sumário executivo do Plano de Ação Nacional para a conservação da ariranha. http://www.icmbio.gov.br/portal/biodiversidade/ fauna-brasileira/plano-de-acao/149-plano-de-acao-nacional-paraconservacao-da-ariranha.html Accessed 11 August 2015 and biology of giant otters in the past 35 years. Bozzetti et al. report on a long-term study of giant otters in a reservoir in Brazil, where they were able to follow reproductive events and provide information on reproductive period, litter size and size of newborns. The nutritional care of a very young cub with artificial formula is described in detail by Cabral et al. Distribution and abundance is a theme extensively dealt with in this special issue. Ayala et al. performed an assessment of giant otter status in northwestern Bolivia and argue that that region along with southeastern Peru represents a major stronghold for giant otters. The Brazilian Pantanal is also an important area for the species, as exemplified by Tomas et al. who found groups in most water bodies of the wetland and estimated a population of 3000-5000 animals. This estimate is as large as the existing estimate of range-wide numbers for the species as a whole (Allen, 2010), suggesting that a concerted effort is necessary to come up with more accurate estimates for the various populations. Evangelista and Tosi present the results of a survey in the previously unassessed Brazilian state of Rondônia, following the IUCN guidelines (Groenendijk et al., 2005), with positive results for all areas surveyed. The same methodology was applied to a survey within Cantão State Park in the northwestern Brazilian Cerrado (an ecotone region between Amazon and Cerrado biomes), where Georgiadis et al. identified 41 individuals in 16 lakes, which represents only a small proportion of the protected area. In another protected area, in the western Brazilian Amazon, Marmontel et al. documented the reappearance of giant otters in an area where they had been considered locally extinct due to hunting in the past. Buschiazzo et al. review past and recent reports of giant otters in Uruguay, where they are suspected to be extinct, and recommend more extensive fieldwork. The recovery of giant otter populations may bring about the issue of giant otter-human conflict due to interactions with fisheries, which is explored by Trujillo et al. in Colombia's Amazonia and Orinoquia. Becerra Cardenas et al. provide a method to identify fish species and estimate their size from premaxillary bones found in giant otter latrines, which may be useful in studies of fishery conflicts that are appearing in different areas. Closing the issue, Groenendijk and Hayek describe a method to sex giant otters in the wild based on the angle they defecate and urinate. Good reading!

\section{Acknowledgments}

We would like to acknowledge all the authors that submitted works that comprise this special issue of LAJAM. We are indebted to the reviewers who helped us in the process of evaluating manuscripts. We are grateful to André G.A. Coelho, Cláudia Rocha-Campos, Daniel Palacios, Lívia A. Rodrigues, Marcelo Lima, Marcelo L. Rheingantz and Victor Utreras, who helped us with an informal review of this introductory article. The image on the cover was graciously contributed by Alyson Melo. Our warmest thanks go to Yaqu Pacha, that allowed the publication of this special issue of LAJAM. 


\section{References}

Allen, D. (2010) Otter. Reaktion Books, London. 183 pp.

Bekoff, M., Daniels, T.J. and Gittleman, J.L. (1984) Life history patterns and the comparative social ecology of carnivores. Annual Review of Ecology and Systematics 15: 191-232.

Caballero, S., Cárdenas, C. and Trujillo, F. (2015) Population structure and genetic diversity of the endangered South American giant otter (Pteronura brasiliensis) from the Orinoco Basin in Colombia: management implications and application to current conservation programs. Journal of Heredity 2015: 469-477. doi:10.1093/jhered/esv0 49 Symposium Article.

Carter, S.K. and Rosas, F.C.W. (1997) Biology and conservation of the giant otter Pteronura brasiliensis. Mammal Review 27(1): 1-26.

Conover, M. (2002) Resolving human-wildlife conflicts - the science of wildlife damage management. Lewis Publishers, Boca Raton, FL. 418 pp.

Davenport, L.C. (2008) Behavior and ecology of the giant otter (Pteronura brasiliensis) in oxbow lakes of the Manu Biosphere Reserve, Peru. Ph.D. Thesis. University of North Carolina, Chapel Hill. 232 pp.

Duplaix, N. (1980) Observations on the ecology and behavior of the giant river otter Pteronura brasiliensis in Suriname. Revue Écologique (Terre et Vie) 34: 495-620.

Foster-Turley, P., Macdonald, S. and Mason, C. (1990) Otters: An Action Plan for their Conservation. UICN/SSC Otter Specialist Group, Gland, Switzerland. 126 pp.

Garcia, D.M., Marmontel, M., Rosas, F.W. and Santos, F.R. (2007) Conservation genetics of the giant otter (Pteronura brasiliensis (Zimmerman, 1780)) (Carnivora, Mustelidae). Brazilian Journal of Biology 67(4): 819-827.

Gittleman, J.L. (1989) Carnivore group living: comparative trends. Pages 183-207 in Gittleman, J.L (ed.) Carnivore behavior, ecology, and evolution. Comstcok Publishing Associates, Ithaca.

Gomez, D.M.V. (2004) Valoración biológica y cultural de la nutria gigante (Pteronura brasiliensis), en el area de influencia de Puerto Carreño, Vichada, Colombia (ríos Orinoco, Bita, Caños Juriepe y Negro). Undergraduate Thesis in Ecology, Pontificia Universidad Javeriana, Bogotá, Colombia. 84 pp.

Gómez, J.R. and Jorgenson, J.P (1999) An overview of the giant otter-fisherman problem in the Orinoco Basin of Colombia. IUCN Otter Specialist Group Bulletin 16(2): 90-96.

Groenendijk, J., Hajek, F., Duplaix, N., Reuther, C., Van Damme, P., Schenck, C., Staib, E., Wallace, R., Waldemarin, H., Notin, R., Marmontel, M., Rosas, F., De Mattos, G.E., Evangelista, E., Utreras, V., Lasso, G., Jacques, H., Matos, K., Roopsing, I. and Botello, J.C. (2005) Surveying and monitoring distribution and population trends of the giant otter (Pteronura brasiliensis) - guidelines for a standardisation of survey methods as recommended by the Giant Otter Section of the IUCN/SSC Otter Specialist Group. Habitat 16: 1-100.
Groenendijk, J., Hajek, F., Johnson, P.J., Macdonald, D., Calvimontes, J., Staib, E. and Schenck, C. (2014) Demography of the giant otter (Pteronura brasiliensis) in Manu National Park, south-eastern Peru: implications for conservation. PLoS ONE 9(8): e106202. doi:10.1371/journal.pone.0106202

Groenendijk, J., Duplaix, N., Marmontel, M., Van Damme, P. and Schenck, C. (2015a) Pteronura brasiliensis. The IUCN Red List of Threatened Species 2015: e.T18711A21938411. http://dx.doi.org/10.2305/IUCN.UK.2015-2.RLTS. T18711A21938411.en. Consulted on 28 August 2015.

Groenendijk, J., Hajek, F., Schenck, C., Staib, E., Johnson, P.J. and MacDonald, D.W. (2015b) Effects of territory size on the reproductive success and social system of the giant otter, south-eastern Peru. Journal of Zoology 296(3): 153-160. doi $10.1111 /$ jzo. 12231

Gutleb, A., Schenck, C. and Staib, E. (1997). Giant otter (Pteronura brasiliensis) at risk? Total mercury and methylmercury levels in fish and otter scats, Peru. Ambio XXVI(8): 511-514.

Kruuk, H. (2006) Otters - ecology, behaviour and conservation. Oxford University Press, Oxford. 265 pp.

Laidler, P.E. (1984) The behavioral ecology of the giant river otter in Guyana. Ph.D. Thesis. University of Cambridge, Cambridge, United Kingdom. 319 pp.

Laidler, K. and Laidler, L. (1983) The River Wolf. George Allen \& Unwin, London.178 pp.

Lasmar, R.P., Lima, D.S. and Marmontel, M. (2013) What do local fishermen from the mid Solimões river think about the giant river otter? Natural Resources 3: 42-48.

Leuchtenberger, C., Oliveira-Santos, L.G.R., Magnusson, W. and Mourão, G. (2013a) Space use by giant otter groups in the Brazilian Pantanal. Journal of Mammalogy 94(2): 320330. doi: 10.1644/12-MAMM-A-210.1

Leuchtenberger, C., Zucco, C.A., Ribas, C., Magnusson, W. and Mourão, G. (2013b) Activity patterns of giant otters recorded by telemetry and camera traps. Ethology Ecology \& Evolution http://dx.doi.org/10.1080/03949370.2013.821673

Leuchtenberger, C., Magnusson, W. and Mourão, G. (2015) Territoriality of giant otter groups in an area with seasonal flooding. PLoS ONE 10(5): e0126073. doi:10.1371/journal.pone.0126073

Lima, D.S. and Marmontel, M. (2011) Return to the wild and reintegration of a giant river otter (Pteronura brasiliensis) cub to its family group in Amanã Sustainable Development Reserve, Brazilian Amazon. Latin American Journal of Aquatic Mammals 9(2): 164-167. http://dx.doi.org/10.5597/lajam00183

Lima, D.S., Marmontel, M. and Bernard, E. (2013) Reoccupation of historical areas by the endangered giant river otter Pteronura bralisiensis (Carnivora: Mustelidae) in Central Amazonia, Brazil. Mammalia 78(2): 177-184. 73 
Lima, D.S, Marmontel, M. and Bernard, E. (2014) Conflicts between humans and giant otters (Pteronura brasiliensis) in Amanã Reserve, Brazilian Amazonia. Ambiente \& Sociedade 17(2): 127-142.

Mason, C.F. and MacDonald, S.M. (2008) Otters: ecology and conservation. Cambridge University Press, Cambridge. 236 pp.

Pickles, R.S.A., Groombridge, J.J., Zambrana Rojas, V.D., Van Damme, P., Gottelli, D., Kundu, S., Bodmer, R., Ariani, C.V., Iyengar, A and Jordan, W.C. (2011a) Phylogeography and identification of evolutionary significant units in the giant otter. Molecular Phylogenetics and Evolution 61: 616-627.

Pickles, R.S.A., Zambrana, Jordan, B., Hoffmann-Heap, I., Salinas, A., Groombridge, J. and Van Damme, P. (2011b) An evaluation of the utility of camera traps in monitoring giant otter populations. IUCN Otter Specialist Group Bulletin 28(1): 39-45.

Pickles, R.S.A., Groombridge, J.J., Zambrana Rojas, V.D., Van Damme, P., Gottelli, D., Ariani, C.V. and Jordan, W.C. (2012) Genetic diversity and population structure in the endangered giant otter. Conservation Genetics 13: 235-245.

Recharte, M. and Bodmer, R. (2009) Recovery of the endangered giant otter Pteronura brasiliensis on the Yavarí-Mirín and Yavarí Rivers: a success story for CITES. Oryx 44(1): 83-88.

Recharte, M., Bowler, M. and Bodmer, R. (2008) Potential conflict between fishermen and giant otter (Pteronura brasiliensis) populations by fishermen in response to declining stocks of arowana fish (Osteoglossum bicirhossum) in Northeastern Peru. IUCN Otter Specialist Group Bulletin 25(2): 89-93.

Ribas, C., Cunha, H.A., Damasceno, G., Magnusson, W.E., Solé-Cava, A. and Mourão, G. (2015) More than meets the eye: kinship and social organization in giant otters (Pteronura brasiliensis). Behavior Ecology and Sociobiology 12 pp. doi 10.1007/s00265-015-2015-7

Ribas, C., Damasceno, G., Magnusson, W., Leuchtenberger, C. and Mourão, G. (2012) Giant otters feeding on caiman: evidence for an expanded trophic niche of recovering populations. Studies on Neotropical Fauna and Environment 47(1): 19-23.

http://dx.doi.org/10.1080/01650521.2012.662795

Ribas Pereira, C. (2004) Desenvolvimento de um programa de monitoramento em longo prazo das ariranhas (Pteronura brasiliensis) no Pantanal brasileiro. M.Sc. Thesis. Universidade Federal de Mato Grosso do Sul. Campo Grande, Brazil. 68 pp.

Rosas, F.C.W., Zuanon, A.S. and Carter, S.K. (1999) Feeding ecology of the giant otter, Pteronura brasiliensis. Biotropica 31(3): 502-506.

Rosas-Ribeiro, P., Rosas, F.C.W. and Zuanon, J. (2011) Conflict between fishermen and giant otters Pteronura brasiliensis in Western Brazilian Amazon. Biotropica 44(3): 437-444. doi 10.1111/j.1744-7429.2011.00828.x
Schenck, C. (1999) Lobo de río Pteronura brasiliensis Presencia, uso del hábitat y protección en el Perú. Ph.D.Thesis. Facultad de Biologia, Universidad Ludwig-Maximilians, Munich. Agencia de Cooperación Técnica Alemana, Sociedad Zoologica de Frankfurt, Proyecto Planificación y Manejo de Áres Protegidas Amazónicas, INRENA-FANPE. 176 pp.

Schweizer, J. (1992) Ariranhas no Pantanal. EDIBRAN, Curitiba. 202 pp.

Silva, R.E., Rosas, F.C.W and Zuanon, J. (2014) Feeding ecology of the giant otter (Pteronura brasiliensis) and the Neotropical otter (Lontra longicaudis) in Jaú National Park, Amazon, Brazil. Journal of Natural History 48: 465-479.

Silveira, L., Furtado, M.M., Rosas, F.C.W., Silva, L.C., Cabral, M.M.M, Torres, N.M., Sollmann, R., Kouba, A. and Jácomo, A.T.A (2011) Tagging giant otters (Pteronura brasiliensis) (Carnivora, Mustelidae) for radio-telemetry studies. Aquatic Mammals 37(2): 208-212.

http://dx.doi.org/10.1578/AM.37.2.2011.208

Staib, E. (2002) Oko-Ethologie von Riesenottern (Pteronura brasiliensis) en Peru. Aachen: Shaker. Ph.D. Thesis [translated into Spanish in 2005 by Ayuda para Vida Silvestre Amenazada - Sociedad Zoologica de Francfort, as Eco-etología del lobo de rio (Pteronura brasiliensis) en el sureste del Perú]. 196 pp.

Utreras, V. and Pinos, L. (2003) Camera trap use for studying giant otters (Pteronura brasiliensis) in the Yasuní Biosphere Reserve, Ecuadorian Amazon. IUCN Otter Specialist Group Bulletin 20(2): 69-71.

Utreras, V., Suárez, E., Zapata-Ríos, G., Lasso, G. and Pinos, L. (2005) Dry and rainy season estimations of giant otter, Pteronura brasiliensis, home range in the Yasuní National Park, Ecuador. The Latin American Journal of Aquatic Mammals 4(2): 191-194. http://dx.doi.org/10.5597/lajam00085

Utreras, V., Trujillo, F. and Usma, S. (2013) Plan de Acción para la Conservación de los Mamíferos Acuáticos en la Amazonía Ecuatoriana. WCS, Fundación Omacha, Ministerio del Ambiente and WWF, Quito, Ecuador.

Yoxon, P., G.M. Yoxon (2014) Otters of the world. Whittles Publishing, Dunbeath, UK. 154 pp.

Zambrana Rojas, V., Pickles, R.S. and Van Damme, P.A. (2012) Abundancia relativa de la londra (Pteronura brasiliensis) en los ríos Blanco y San Martín (cuenca del río Iténez, Beni-Bolivia). Pages 183-193 in Van Damme, P.A., Maldonado, M., Pouilly, M. and Doria, C.R.C. (Eds). Aguas del Iténez-Guaporé: recursos hidrobiológicos de un patrimonio binacional (Bolivia y Brasil). Editorial INIA, Cochabamba, Bolivia. 420 pp. 